\title{
NOVEL VERTICAL ECOSYSTEM FOR SUSTAINABLE WATER TREATMENT AND REUSE IN TOURIST RESORTS
}

\author{
H. GATTRINGER ${ }^{1}$, A. CLARET ${ }^{2}$, M. RADTKE ${ }^{3}$, J. KISSER ${ }^{1}$, A. ZRAUNIG ${ }^{1}$, \\ I. RODRIGUEZ-RODA ${ }^{4} \&$ G. BUTTIGLIERI ${ }^{4}$ \\ ${ }^{1}$ Alchemia-nova $\mathrm{GmbH}$, institute for innovative phytochemistry \& closed loop processes, Vienna, Austria. \\ ${ }^{2}$ LEITAT Technological Center, R\&D Safety \& Sustainability Division, Terrassa, Spain. \\ ${ }^{3}$ Radtke Biotechnik, Veitshöchheim, Germany. \\ ${ }^{4}$ ICRA, Catalan Institute for Water Research, Girona, Spain.
}

\begin{abstract}
A greywater treatment and reuse technology based on a living ecosystem, which is integrated into a hotel is presented. Benefits include considerable water savings, optical enhancement of the premises, clear green image, improved local microclimate, and reduced ecological footprint. The Vertical Ecosystem (VertECO) consists of an indoor constructed wetland, combining sub-surface horizontal water flow with stage-wise vertical flow. Plants function in symbiosis with rhizosphere microorganisms providing remarkable water cleaning abilities. The unit can be located either indoors or outdoors and is designed to be placed on walls (interior/exterior). Pollution abatement in the range of $90 \%$ or higher is achieved, with the effluent being clear, odorless water. The effluent meets regulatory quality standards for several reuses, including garden irrigation, golf course irrigation, toilet flushing, and others. Water savings of 40\%-50\% can be achieved. Operation costs are much lower than the costs of fresh tap water. Data showing the cleaning performance of the unit is presented, as well as environmental Life Cycle Assessment (LCA) data, which points toward a favorable ecological footprint when compared to current common water management practice in touristic resorts and municipalities.

Keywords: constructed wetlands, decentralized water treatment, ecosystem services, greywater reuse, water pollution abatement, water preservation.
\end{abstract}

\section{INTRODUCTION}

Since the early 1950s, constructed wetlands are known to filter pollutants from water. These treatment systems use natural processes involving wetland vegetation, soil substrates, and their associated microorganism to improve water quality [1]. Wetland plants offer proper conditions for microorganisms to live in the rhizosphere. Through a series of metabolic processes, these microorganisms transform and remove pollutants from water [2].

Greywater reuse for applications with lower water quality requirements like toilet flushing, irrigation, or groundwater recharge is not new. Due to the low contamination with pathogens as compared to blackwater, the reuse of treated greywater can be attractive for decentralized solutions [3]. Most plant-based wastewater treatment units are usually located outdoors. Often they are centralized and operated by companies or community services and infrastructure providers. There are some efforts that aim to treat greywater decentralized and on-site at buildings, but these are all designed as outdoor solutions. Only a few horizontal indoor-constructed wetlands are known $[4,5]$.

Due to space limitations, Greenwalls (vertical greening elements) are already known as an architectural gardening structure [6]. These living walls or green roofs are often used to \footnotetext{
This paper is part of the Proceedings of the $7^{\text {th }}$ International Conference on Sustainable Tourism
(Sustainable Tourism 2016)

www.witconferences.com
} 
reduce overall temperature of buildings, improve air quality, buffer noise, but mostly for aesthetic purposes. The combination of a vertical constructed wetland integrated into an indoor design setting of a building is a new concept. The Vertical Ecosystem (VertECO) presented here treats greywater reducing drinking water consumption by allowing on-site water reuse, for example for flushing toilets. This ecosystem-friendly technology is based on subsurface water flow through the root zone of plants [7]. The investigated plant species function in symbiosis with rhizosphere-specific microorganisms providing intrinsic water cleaning abilities. In fact, this also helps to remove volatile organic compounds (VOCs) from the ambient air [8].

Particularly in Mediterranean countries and regions with an arid climate, water resources are limited and unequally distributed in space and time. This leads to a mismatch between fresh water availabilty and water demand, especially in areas with high touristic activity in summers. Water consumption per guest and day has been estimated at an average of $222 \mathrm{~L} /$ day in hotels in Spain [9], but higher consumptions have been reported. Add to this the consideration that Lloret der Mar, the coastal town where the pilot plant discussed in this article is located, has a population of some 40.000 inhabitants, which during the touristic high season in summer swells up to 200.000, which also happens to be the dry season in terms of rainfalls and river water flows. This illustrates the challenges posed to the drinking water supply of Mediterranean touristic centers.

\section{UNIT DESCRIPTION AND METHODS}

\subsection{Description of the VertECO pilot plant}

The pilot unit is located in Hotel Samba, a representative hotel located in Lloret de Mar, Girona, Spain. It is a large resort with 441 air-conditioned rooms, green areas and exterior pools, conference rooms, bar, and restaurant. It is certified by EMAS and ISO 14001.

For the constructed wetland, a vertical stage-wise setup has been used, combined with a sub-surface horizontal water flow. The pilot small-scale wetland consists of four floors, connected by water tubes. A pump, with time controlled operation, feeds greywater from a buffer tank into the top floor at regular time intervals. Current greywater input flow is $1 \mathrm{~m}^{3} /$ day. Water flows in a sub-surface horizontal manner, meandering through the rhizosphere and is pushed down to the next floors by gravity. In order to improve the aerobic symbiosis of roots and microorganisms [10], air is continuously injected through perforated hoses at the bottom of the plant containers. As an additional benefit, air-pollutants and particulates are also removed from the air through this aeration system. Harmful air-pollutants can be metabolized by microorganisms in the root zone, some are absorbed directly by plants as reported by Wolverton [8]. To ensure the largest possible area for the colonization of microorganisms, an inorganic substrate with a large surface area (e.g. expanded clay) has been selected as the planting substrate [11]. The substrate is also structure-stable and does not biodegrade over time, so that it does not break up and clog any pipes. The investigated plant species are specifically suitable for this indoor constructed wetland system and have some decorative qualities (see Fig. 1).

Overall spatial footprint of the demonstration unit is $5 \mathrm{~m}$ in length, $1.50 \mathrm{~m}$ in width and $2.50 \mathrm{~m}$ in height. Total root substrate volume is $2 \mathrm{~m}^{3}$. The VertECO pilot plant has been constructed within a cooperative European research project, called demEAUmed (www. demeaumed.eu), which demonstrates and studies several water treatment and recycling technologies in an exemplary project. 


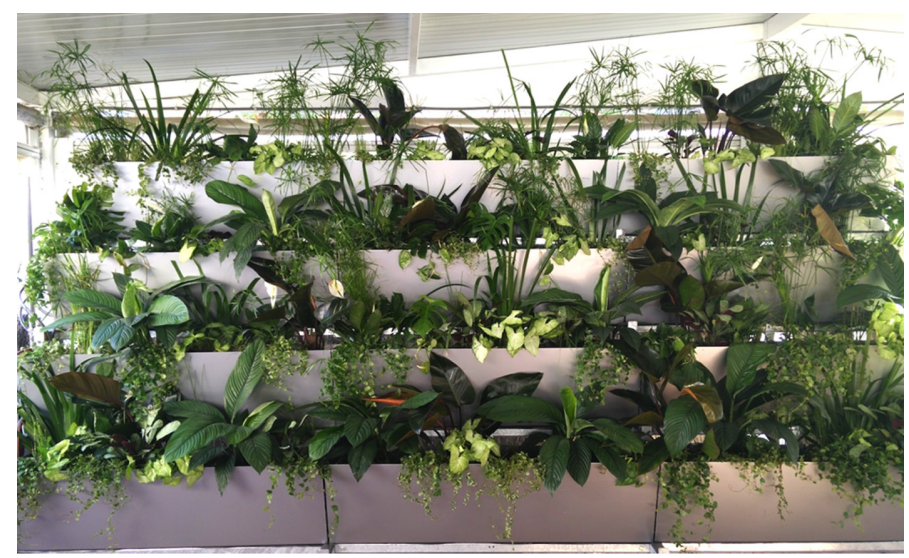

Figure 1: Picture of the actual pilot unit at the demonstration site. The four functional floors are clearly visible.

Greywater at the hotel consists of shower and lavatory effluents from the guest rooms, which are collected centrally in a greywater tank during the daily business operation of the hotel. For the research presented here, some of this greywater $\left(1 \mathrm{~m}^{3}\right.$ per day $)$ is diverted toward the VertECO unit for trials. The greywater is pumped into an aerated pre-treatment tank and from there it is pumped at periodical intervals into the constructed wetland.

\subsection{Water quality analysis}

Water samples were constantly taken at two collection points: directly from the greywater pipes from the hotel (inffluent water quality), and then after wetland treatment, i.e. directly after the last treatment stage (effluent water quality). Samples were taken from July to December 2015. Different parameters were analyzed, of 7 and 18 times each, by ICRA (Catalan Institute for Water Research) at their accredited laboratories in Girona, Spain. Many different physical and chemical parameters that define water quality are analyzed (see Table 1). Many micropollutants were also selected for analysis based on the fact that they were most frequently detected in previous sampling campaigns at the same hotel. The endocrine disrupting compounds (EDs) were estrone, estradiol, bisphenol A, methylparaben, ethylparaben, propylparaben, triclosan, caffeine, testosterone, tris (2-chloroisopropyl) phosphate, and tris (2-butoxyethyl) phosphate.

The pharmaceutical active compounds (PCs) were acetaminophen, diclofenac, ibuprofen, iopromide, ketprofen, salicylic acid, sulfamethaoxazole, and trimethoprim. EDCs were analyzed by ultra-high performance Liquid Chromatography coupled with tandem Mass Spectrometry (TSQ Vantage, Thermo Scientific) with limit of detection between 0.1 and 5.0 ng/L. PCs were analyzed by ultra-high performance Liquid Chromatography coupled with triple quadrupole-linear ion trap mass spectrometer (5,500 QqLit) with limit of detection between 0.12 and $14.0 \mathrm{ng} / \mathrm{L}$ [12].

\subsection{Life cycle assessment methods}

To quantitatively assess the environmental impacts of VertECO technology, the Life Cycle Assessment (LCA) methodology has been applied in this study. This is a multivectorial tool 
Table 1: Standard methods used to determine the physical and chemical water quality parameters used, according to Greenberg [12].

\begin{tabular}{lll}
\hline Water quality parameters & \\
\hline & Analysis method & ISO Number or standard procedure \\
\hline Alicalinity & Potentiometry & Norm UNE-ENISO 9963-1 (ISO 9963-1: 1994 \\
TOC & Catalytic oxidation & Method adapted from UNE-EN 1484 \\
COD & Digestion+potentiometric & Norm UNE 77004 \\
& quantification & \\
BOD & Respirometry & Greenberg, A. E. 2005. Standard Methods \\
Conductivity & Potentiometry & Norm UNE EN 27888 \\
pH & Potentiometry & Norm UNE 77078 \\
TSS & Filtration and weight & Norm UNE 77031:2002 \\
VSS & Filtration and weight & Norm UNE 77031:2002 \\
TN & Catalytic oxidation & Norm UNE-EN 12260: 2003 \\
TKN & Digestion & Norm UNE-EN 25663 \\
N-NO2 & Ion chromatography & Norm UNE-EN ISO 10304-2: 1997 \\
N-NO3 & Ion chromatography & Norm UNE-EN ISO 10304-2: 1997 \\
N-NH4 & Ion chromatography & Norm UNE-EN ISO 14977:2000 \\
P-PO4 & Ion chromatography & Norm UNE-EN ISO 10304-2: 1997 \\
\hline
\end{tabular}

that evaluates the environmental burdens associated to a product, process, or service throughout its life cycle (from raw materials extraction to the end-of-life management). The LCA methodology is based on ISO 14040:2006 [13]. The LCA of VertECO has been carried out by the R\&D Safety \& Sustainability Division of LEITAT Technological Center, located in Terrassa (Barcelona), Spain.

The functional unit (FU) of $1 \mathrm{~m}^{3}$ of treated water has been defined. Four life cycle stages of VertECO technology have been considered in the environmental analysis: the materials and components necessary for installation, the transport of all the different components to the final location at the hotel in Lloret de Mar, the growing stage of the plants in greenhouse nurseries prior to planting into the constructed wetland, and finally the operation and maintenance stage (which is mostly electricity consumption of pumps). For all the materials and components a cradle to gate perspective has been applied to determine the environmental assessment of the installation. Sludge generation is minimal and some $50 \mathrm{~kg}$ per year of biomass is produced. The end-of-life of the unit and the biomass have not been considered for the study, because their impacts have been found negligible. Inventory data was provided by alchemia-nova $\mathrm{GmbH}$ and general data was obtained from $\mathrm{GaBi}$ and Ecoinvent Databases. A lifespan of 10 years and an operation time of $24 \mathrm{~h}$ per day have been assumed for the unit. There are basically no materials or chemicals consumption to consider during the operation and maintenance stage. Replacement of $5 \%$ of the plants per year of the constructed wetland has been considered.

A set of characterization factors have been used, based on the impact assessment method ILCD 2011 midpoint [14]. 11 environmental impact categories were analyzed: acidification, 
climate change, freshwater ecotoxicity, freshwater eutrophication, marine eutrophication, human toxicity (cancer effects), human toxicity (non-cancer effects), ozone depletion, photochemical ozone formation, water resource depletion and mineral, fossil and renewable resource depletion. Calculations have been done using the GaBi 6 software [15].

\section{RESULTS}

\subsection{Pollution abatement performance}

Greywater fed into the VertECO demonstration unit is light greyish in color and smells of muddy detergents. The outflow from the unit is clear odorless water. Quantified physicochemical parameters for the inflow and outflow streams are presented in Table 2, based on the results by ICRA. The percentage quotient of the pollution abatement corresponding to each parameter is also shown. To better illustrate the results, the graphic in Fig. 2 has been prepared. The standard deviation is indicated by the T-lines on the top of the columns of the graphs.

Removal of EDs and PCs by VertECO are shown in Tables 3 and 4. EDs were found in the inflow at 5,683 and 19,725 ng/L for ethylparaben and caffeine respectively, while in the outflow the highest concentration was $255 \mathrm{ng} / \mathrm{L}$ for bisphenol A. Removal of EDs was extremely high and close to $100 \%$ in most analyzed compounds, with the exception of bisphenol A, tris(2-chloroisopropyl) phosphate and tris(2-butoxyethyl) phosphate, where the removal rate can be as low as $40 \%$. Particularly, the removal capacity of the parabens seems very impressive, given their comparatively high inflow concentration uo 6,673 ng/L. As regard to PCs the maximum detected influent concentration was for acetaminophen with 2,614 ng/L and 553 $\mathrm{ng} / \mathrm{L}$ for ibuprofen in the outflow. The removal rates of the PCs were all above $60 \%$, with

Table 2: Water pollution abatement results for the VertECO unit.

\begin{tabular}{llrrr}
\hline Parameter & Unit & Inflow & Outflow & Removal (\%) \\
\hline Alcalinity & mgCaCO3/L & 156.03 & 141.39 & 9.4 \\
TOC & $\mathrm{mgC} / \mathrm{L}$ & 50.76 & 6.09 & 88.0 \\
COD & $\mathrm{mgO} 2 / \mathrm{L}$ & 409.11 & 13.89 & 96.6 \\
BOD & $\mathrm{mgO} / \mathrm{L}$ & 130.32 & 3.81 & 97.1 \\
Conductivity & $\mu \mathrm{S} / \mathrm{cm}$ & 817.61 & 774.34 & 5.3 \\
pH & - & 7.25 & 7.43 & \\
TSS & $\mathrm{mg} / \mathrm{L}$ & 336.09 & 3.98 & 98.8 \\
VSS & $\mathrm{mg} / \mathrm{L}$ & 233.34 & 2.20 & 99.1 \\
TN & $\mathrm{mgN} / \mathrm{L}$ & 16.17 & 4.21 & 74.0 \\
TKN & $\mathrm{mgN} / \mathrm{L}$ & 27.03 & 1.63 & 94.0 \\
N-NO2 & $\mathrm{mg} / \mathrm{L}$ & 5.25 & 0.20 & 96.2 \\
N-NO3 & $\mathrm{mg} / \mathrm{L}$ & 0.67 & 3.61 & -440.3 \\
N-NH4 & $\mathrm{mg} / \mathrm{L}$ & 4.89 & 0.17 & 96.6 \\
P-PO4 & $\mathrm{mg} / \mathrm{L}$ & 1.26 & 0.32 & 74.6 \\
\hline
\end{tabular}




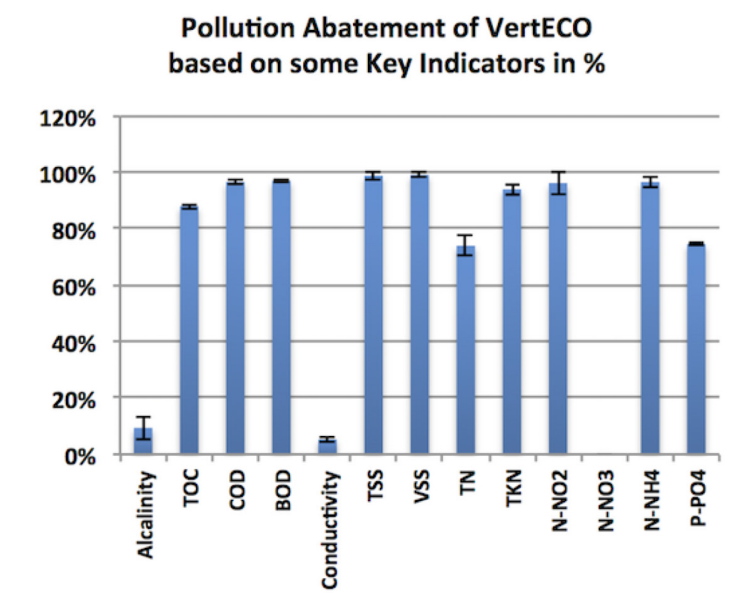

Figure 2: Water cleaning performance of the VertECO unit.

Table 3: Abatement of endocrine disruptors in treated water.

\begin{tabular}{lcrrr}
\hline Prameter & Unit & \multicolumn{1}{c}{ Inflow } & Outflow & Removal (\%) \\
\hline Estrone & $\mathrm{ng} / \mathrm{L}$ & 58.84 & 0.04 & 99.9 \\
Estradiol & $\mathrm{ng} / \mathrm{L}$ & 0.54 & 0.00 & 100.0 \\
Bisphenol A & $\mathrm{ng} / \mathrm{L}$ & 507.38 & 255.31 & 49.7 \\
Methylparaben & $\mathrm{ng} / \mathrm{L}$ & 6672.54 & 36.55 & 99.5 \\
Ethylparaben & $\mathrm{ng} / \mathrm{L}$ & 5683.05 & 2.08 & 100.0 \\
Propylparaben & $\mathrm{ng} / \mathrm{L}$ & 1853.40 & 8.23 & 99.6 \\
Triclosan & $\mathrm{ng} / \mathrm{L}$ & 31.98 & 0.00 & 100.0 \\
Caffeine & $\mathrm{ng} / \mathrm{L}$ & 19724.93 & 94.60 & 99.5 \\
Testosterone & $\mathrm{ng} / \mathrm{L}$ & 137.67 & 1.87 & 98.6 \\
Tris(2-chloroisoprapyl) phosphate & $\mathrm{ng} / \mathrm{L}$ & 374.67 & 226.48 & 39.5 \\
Tris(2-butoxyethyl) phosphate & ng/L & 104.69 & 27.58 & 73.7 \\
& LOD between $\mathbf{0 . 1}$ and 5.0 ng/L & & \\
\hline
\end{tabular}

most over $80 \%$ and some even reaching $100 \%$ removal rate. Of note is the prevalence of comparatively high concentrations of pain killers in the inflow of the test site (acetaminophen and ibuprofen) as well as the high level of salicylic acid, which is the compound found in classical Aspirins.

\subsection{LCA results}

Figure 3 shows the environmental impact contributions of each life cycle stage of VertECO for the selected impact categories per functional unit. In most categories the materials have the greatest impact contributions. In the climate change and water resource depletion categories the operation stage of VertECO appears to have a larger impact contribution than the 
Table 4: Abatement of pharmaceutical compounds in treated water by the VertECO demonstration unit.

\begin{tabular}{lllll}
\hline Parameter & Unit & Inflow & Outflow & Removal (\%) \\
\hline acetaminophen & ng/L & 2614.49 & 301.54 & 88.5 \\
diclofenac & ng/L & 210.02 & 39.19 & 81.3 \\
Ibuprofen & ng/L & 1967.02 & 553.29 & 71.9 \\
Iopromide & ng/L & 4.27 & 0.00 & 100.0 \\
ketprofen & ng/L & 122.07 & 15.01 & 87.7 \\
salicylic acid & ng/L & 1986.62 & 249.31 & 87.5 \\
sulfamethoxazole & ng/L & 5.99 & 2.32 & 61.3 \\
trimethoprim & ng/L & 2.94 & 0.00 & 100.0 \\
& LOD between $\mathbf{0 . 1 2}$ and $\mathbf{1 4 . 0}$ ng/L & \\
\hline
\end{tabular}

Relative Importance of Different Life Stages of the VertECO Unit on Environmental Impact Indicators

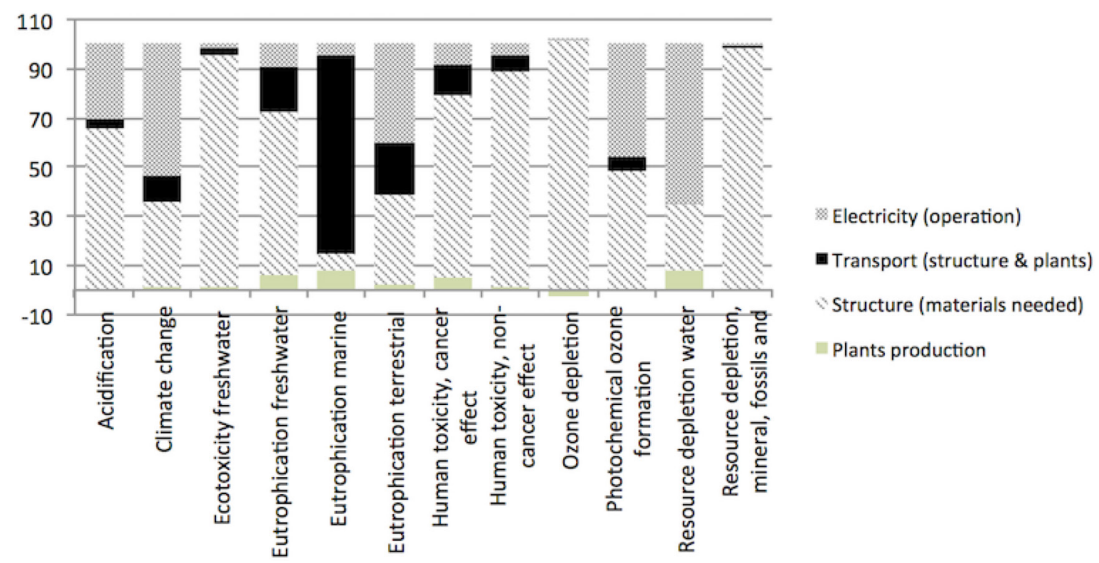

Figure 3: Environmental impact of four different life stages for VertECO.

other life cycle stages. Only in marine eutrophication does the transport stage play a bigger role than the others. Plant production adds a little positive credit in the ozone depletion impact category, while adding little impact contribution in most other impact categories. This of course invites to take a closer look at the components and materials of the constructed wetland. This can be seen in Fig. 4.

It is obvious that the largest contributions to environmental impacts stem from the wetland structure components (which are made from galvanized iron) and the plant containers, which are made from high grade stainless steel. Only in two water-related impact categories, Freshwater Eutrophication and Water Resource Depletion, does the substrate used for planting the wetland play a dominant role in terms of environmental impact contributions. Incidentally, these two components are by far the biggest material mass contributors to the whole constructed wetland, besides the plant biomass. 


\section{Relative Environmental Impact of different Material Components of the VertECO Unit}

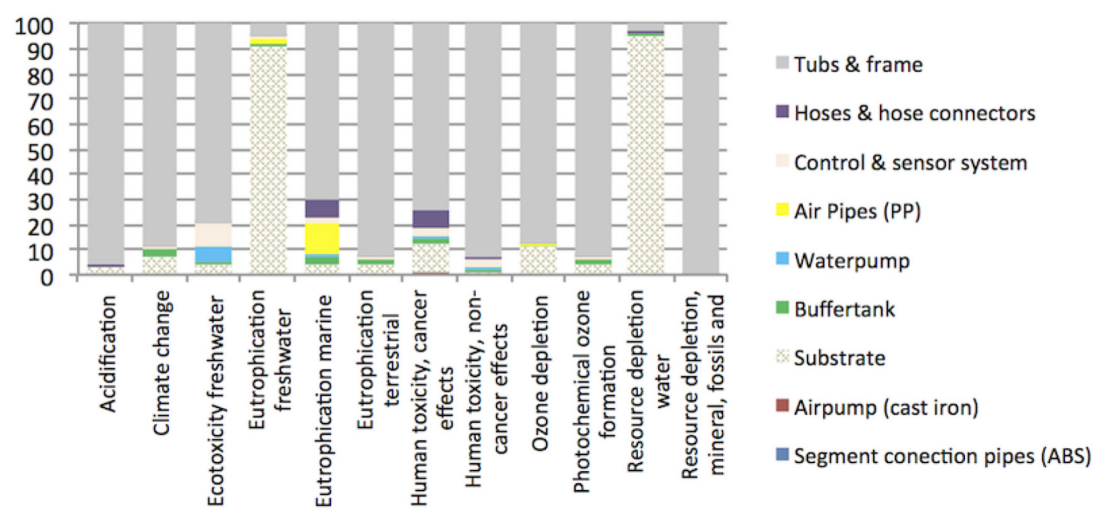

Figure 4: Environmental impact of different components of VertECO.

Table 5: Environmental footprint of VertECO compared with other options.

\begin{tabular}{lcc}
\hline & $\begin{array}{c}\text { Carbon footprint } \\
\text { (kg CO } \text { Cquiv. }^{\mathbf{2}} \text { }\end{array}$ & $\begin{array}{c}\text { Water footprint } \\
\text { ( }^{\mathbf{3}} \text { water equiv.) }\end{array}$ \\
\hline VertECO operational stage & 1.146 & 0.0155 \\
VertECO + PV energy supp. oper. stage & 0.086 & 0.0091 \\
Desalination plant [16] & 0.594 & 0.0080 \\
Tap water from surface water & 0.0006 & 0.0002 \\
WWT plant (incl. ww collection) [17] & 0.96 & 0.0035 \\
\hline
\end{tabular}

A sensitivity analysis has been performed considering that VertECO technology uses solar energy from a photovoltaic installation located on-site. This scenario reduces the environmental impacts of the VertECO operation stage in 9 out of 11 impact categories, highlights are reductions of $57 \%$ in the water resource depletion category and $45 \%$ in the climate change category, avoiding $1.06 \mathrm{~kg} \mathrm{CO}_{2}$ eq. emissions per functional unit.

For the operational stage, a comparison of the environmental profile of VertECO with that of a desalination plant, tap water, and a wastewater treatment plant (WWT) has been performed, considering the FU of $1 \mathrm{~m}^{3}$ of treated water. The results of this analysis are presented in Table 5.

Environmental data about these current technologies have been obtained from GaBi database or from literature. The environmental indicators selected for the comparison are Carbon Footprint ( $\mathrm{kg} \mathrm{CO}_{2}$ eq.) and Water Footprint ( $\mathrm{m}^{3}$ water eq.). For comparison purposes, the theoretical footprints of the VertECO unit using photovoltaics to power the electrical systems is also shown.

At first sight it appears that the carbon and water footprint of the VertECO technology is higher than, for example, the carbon and water footprint of a desalination plant. It is necessary to state though, that the VertECO wetland per design allows the reuse of the greywater it treats, thereby reducing the need to consume more fresh water and avoiding the impacts of producing $1 \mathrm{~m}^{3}$ of additional desalinated water (or $1 \mathrm{~m}^{3}$ of tap water), and also avoids the impacts of treating $1 \mathrm{~m}^{3}$ extra of greywater in a wastewater treatment plant. Therefore, if all the water treated by VertECO is reused (for example for closet flushing) the user in effect gets 
the benefit of the services of $2 \mathrm{~m}^{3}$ of water for each $\mathrm{m}^{3}$ treated by the wetland. A fair comparison would thus be reflected in the following calculation:

Impacts of $\left(1 \mathrm{~m}^{3}\right.$ of water desalination $)+\left(1 \mathrm{~m}^{3}\right.$ of VertECO treatment $)+$

$\left(1 \mathrm{~m}^{3}\right.$ treatment in a WWT)

against

Impacts of $\left(2 \mathrm{~m}^{3}\right.$ of water desalination $)+\left(2 \mathrm{~m}^{3}\right.$ water treatment in a WWT $)$

The results of this calculation would be $2.70 \mathrm{~kg} \mathrm{CO}_{2}$ equiv. for the variant including the VertECO treatment versus $3.11 \mathrm{~kg} \mathrm{CO}_{2}$ equiv. for the variant of using only water from a desalination plant without recycling. This equates to an overall improvement of about $13 \%$ in the carbon footprint of water use. The water footprint seemingly is higher for the VertECO variant in this calculation, but the fact that about $1 \mathrm{~m}^{3}$ of water is actually being preserved through its operation is not factored in. The values for tap water are much lower regarding the carbon footprint, but in areas with critical water shortage during the main tourist season, the need to save water and reduce water depletion at the natural source is probably an imperative that allows no other option.

\section{DISCUSSION AND OUTLOOK}

The water treatment abilities of the constructed wetland (VertECO) are very satisfactory. This is especially clear when comparing the water quality parameters of the outflow from the pilot unit to water quality guidelines determined by Spanish legislation for various water reuse scenarios (see Table 6). Microbiological analysis have not yet been carried out at the pilot site, but are planned in the coming months. However, from previous greywater analysis campaigns done at the same hotel, almost no viable microbes could be found in greywater samples. Previous laboratory trials of VertECO units have shown a reduction of $\log 2$ to $\log 3$ in the populations of E. coli and Intestinal Enterococci, so no concerns are anticipated in this regard.

The finding that nitrate content is actually increased in the outflow of the pilot unit relative to inflow levels (see Table 2) is most likely due to the fact that most $\mathrm{NH}_{4}$-nitrogen is converted to $\mathrm{NO}_{3}^{-}$; but, because of intensive aeration of the substrate the denitrification process seems to be slower than desired. Coupled with the fact that energy consumption of the pilot plant could be optimized, a reduction in the amount of oxygenation will be attempted in the coming months. This optimization should improve the environmental profile of VertECO, while improving the removal of nitrate from the treated water.

Several laboratory trials have confirmed the fact that the vertical ecosystem is not effective in reducing the conductivity parameter of the treated water. Many inorganic anions (like sodium and sulfates) are very prevalent in soaps and detergents. While the organic components of soaps and polluting agents in the hotel effluent are readily consumed and degraded by microorganisms as a source of nutrients and energy, the inorganic anions that are left over are absorbed at a much slower pace by plants and biofilms, thereby leading to unimproved conductivity readings. Yet, the absolute conductivity value of the outflow is still good enough for all the water reuse options that are suggested.

The compounds subsumed as endocrine disruptors are all of organic nature and seem very amenable to biological breakdown through the activity of microorganisms in the constructed wetland. Bisphenol-A is a very common plasticizer in synthetics. Some of the hoses that are used in the pilot plant, which are partially made of PVC, seem to be actually contributing 
Table 6: Water quality requirements for several reuses and the results obtained by VertECO

\begin{tabular}{|c|c|c|c|c|c|}
\hline & & \multicolumn{2}{|c|}{ CATEGORY 3} & \multicolumn{2}{|l|}{ CATEGORY 4} \\
\hline \multirow[t]{2}{*}{ USES } & & \multicolumn{2}{|c|}{ Irrigation } & \multirow[t]{2}{*}{ Toilet flushing } & \multirow{4}{*}{$\begin{array}{l}\text { Vertical } \\
\text { ecosystem } \\
\text { results }\end{array}$} \\
\hline & & $\begin{array}{l}\text { Private } \\
\text { garden } \\
\text { irrigation }\end{array}$ & $\begin{array}{c}\text { Golf } \\
\text { irrigation }\end{array}$ & & \\
\hline \multirow{2}{*}{$\begin{array}{l}\text { LEGISLATION } \\
\text { (if present) }\end{array}$} & European & 91/271/EC & 91/271/EC & 91/271/EC & \\
\hline & Spanish & $\begin{array}{c}\text { RD } \\
1620 / 2007\end{array}$ & $\begin{array}{c}\text { RD } \\
1620 / 2007\end{array}$ & RD 1620/2007 & \\
\hline \multirow[t]{10}{*}{ Key Parameter } & $\begin{array}{l}\text { Escherichis coli } \\
\text { (CFU/100 mL) }\end{array}$ & 0 & 200 & 0 & n.d. \\
\hline & $\begin{array}{l}\text { Instestinal } \\
\text { nematodes } \\
(\text { egg/10 L) }\end{array}$ & 1 & 1 & 1 & n.d. \\
\hline & $\begin{array}{l}\text { Legionella } \\
\text { (CFU/100 mL) }\end{array}$ & 100 & 100 & 100 & n.d. \\
\hline & COD (mg/L) & 125 & 125 & & 13.9 \\
\hline & BOD5 (mg/L) & 25 & 25 & & 3.88 \\
\hline & TSS (mg/L) & 10 & 20 & 10 & 4.0 \\
\hline & $\begin{array}{l}\text { Conductivity } \\
(\mu \mathrm{s} / \mathrm{cm})\end{array}$ & 6,000 & & & 774 \\
\hline & $\begin{array}{l}\text { Total Notrogen } \\
(\mathrm{mg} / \mathrm{L})\end{array}$ & & & & 4.2 \\
\hline & Nitrate (mg/L) & & & & 3.6 \\
\hline & $\begin{array}{l}\text { Turbidity } \\
\text { (NTU) }\end{array}$ & 2 & 10 & 2 & 0.3 \\
\hline
\end{tabular}

some bisphenol-A to the outflow of the unit, which may be a reason for its removal rate not being so good. Hoses with less or other types of plasticizers may bring an improvement here. The removal of pharmaceuticals is quite good and this will be researched further with additional compounds and with general performance increases through better water flow management.

The LCA has shown that the components made of stainless steel or galvanized iron have considerable environmental impacts. Future work will comprise an environmental assessment of alternative materials, such as plastic or wood, for the manufacture of the containers, with the aim to diminish the global environmental impact of VertECO. The other very obvious result from the environmental assessment is the fact that electric energy consumption during the operation stage of the unit has a major impact on the sustainability balance of the technology. As studied, the VertECO pilot plant at the hotel in Lloret de Mar consumes about 2.7 $\mathrm{kWh}$ of electricity per $1 \mathrm{~m}^{3}$ of treated water. This makes economic sense, since at the current price of electricity $(0.1275 € / \mathrm{kWh})$ and water $\left(1.59 € / \mathrm{m}^{3}\right.$ including sewage and WWT costs) in Spain, the treated water has a cost of $0.345 € / \mathrm{m}^{3}$, which is much cheaper than tap water (note that this does not include the depreciation costs of the investment to install the unit). 
As has been noted, some possible optimizations to reduce consumption of electric energy have been identified and are easy to implement. Further, the excellent water cleaning performance of the vertical ecosystem seemingly allows to significantly increase the throughput of greywater. Results so far suggest that with the same unit $1.5 \mathrm{~m}^{3}$ or even $2 \mathrm{~m}^{3}$ of water could be treated per day without running the risk of exceeding any quality parameter limit demanded for different reuse scenarios (see Table 6). This increase in throughput would have a significant effect on the economic benefit of the unit, as well as on most the environmental impact parameters. Further, for the current year, installation of a photovoltaic energy supply to feed the VertECO unit is planned. This will further improve the environmental performance and carbon footprint of the technology, by reducing the environmental impact on climate change impact category by $45 \%$, an absolute reduction of about $1.06 \mathrm{~kg}$ of CO 2 eq. per functional unit.

Regarding all the environmental impact categories outlined in this article, those results have to be weighed against the water savings enabled by the technology, which are very considerable throughout its lifetime. This criteria becomes especially critical in regions with yearly acute water scarcity during dry periods, such as the tourist high season during summers. For many regions around the Mediterranean, implementation of intelligent water preserving strategies is a necessity.

Finally, all economic and environmental benefits of the VertECO technology can be further leveraged through its compelling possibilities for green building design, integration with inhabitated spaces, and embellishment of buildings. This demonstration of the benefits that an ecosystem provides, especially with regard to clean water and pleasant living conditions, have great educational value. The possibility to install VertECO technologies indoors also allows countries with cold winters to benefit from this solution. The technology can of course also be installed in homes, office buildings, and other premises. Some industries with wastewaters rich in organic pollutants (e.g. food processing industries or paper and pulp industries) could also benefit greatly from this solution.

\section{ACKNOWLEDGMENTS}

This study has been made possible through the assistance of the European Union (Grant agreement $\mathrm{N}^{\circ}$ 619116). The contents of this document are the sole responsibility of demEAUmed Consortium.

\section{REFERENCES}

[1] Brix, H., Treatment of wastewater in the rhizosphere of wetland plants - the root zone method. Water Science and Technology, 19(1/2), pp. 107-118, 1987.

[2] Vymazal, J., Brix, H., Copper, P.F., Haberk, R., Perfler, R. \& Laber, R., Removal mechanisms and types of constructed wetlands. Constructed Wetlands for Wastewater Treatment in Europe, pp 17-66, 1998.

[3] Li, F., Wichmann, K. \& Otterpohl, R., Review of the technological approaches for grey water treatment and reuses. Science of the Total Environment, 407, pp. 3439-3449, 2009. http://dx.doi.org/10.1016/j.scitotenv.2009.02.004

[4] Starkl, M., Binner, E., Fürhacker, M., Holubar, P., Koeck, S., Lenz, K., Mascher, F. Ornetzeder, M., Pollak, M. \& Haberl, R., Nachhaltige Strategien der Abwasserentsorgung im ländlichen Raum - SUS-SAN Research Projekt - Final Report, August, 2005. 
[5] Weissenbacher, N. \& Müllegger, E., Combined greywater reuse and rainwater harvesting in an office building in Austria: analyses of practical operation. Sustainable Sanitation Practice, 10(1), pp. 4-9, 2009.

[6] Timur, Ö.B. \& Karaca, E., Vertical gardens. In Advances in Landscape Architecture, ed. M. Ozyavuz, Intech, pp. 587-622, 2013.

[7] Vymazal, J., Constructed wetlands for wastewater treatment: five decades of experience. Environmental Science Technologies, 45, pp. 61-69, 2011. http://dx.doi.org/10.1021/es101403q

[8] Wolverton, B.C., Johnson, A. \& Bounds, K., Interior landscape plants for indoor air pollution abatement, National Aeronautics and Space Administration, Stennis Space Centre, Mississippi, 1989, available at http://ntrs.nasa.gov/archive/nasa/casi.ntrs.nasa. gov/19930073077.pdf

[9] Gössling, S., Peeters, P., Hall, M.C., Ceron, J.-P., Dubois, G., Lehmann, V. \& Scott, D., Tourism and water use: supply, demand, and security. An international review. Tourism Management, 33, pp. 1-15, 2012.

http://dx.doi.org/10.1016/j.tourman.2011.03.015

[10] Stottmeister, U., Wießner, A., Kuschk, P., Kappelmeyer, U., Kästner, M., Bederski, O., Müller, R.A. \& Moormann, H., Effects of plants and microorganisms in constructed wetlands for wastewater treatment. Biotechnology Advances, 22, pp. 93-117, 2003. http://dx.doi.org/10.1016/j.biotechadv.2003.08.010

[11] Geller, G., Kleyn, K. \& Lenz, A., Planted soil filters for wastewater treatment: the complex system "Planted Soil Filter", its components and their development. In Constructed Wetlands in Water Pollution Control, eds. P.F. Cooper \& B.C. Findlater, Pergamon Press: Oxford, UK, pp. 161-170, 1990. http://dx.doi.org/10.1016/B978-0-08-040784-5.50020-6

[12] Standard Methods Organization for the Examination of Water \& Wastewater, USA, available at http://www.standardmethods.org

[13] ISO (International Organisation for Standardisation), ISO 14040. Environmental management - Life Cycle Assessment - Principles and Framework, International Organisation for Standardisation: Gènova, 2006.

[14] European Comission - Joint Research Centre - Institute for Environment and Sustainability: International Reference Life Cycle Data System (ILCD) Handbook - General guide for Life Cycle Assessment - Detailed guidance. 1st edn., Luxembourg, 2011.

[15] GaBi software is developed by THINK STEP, available at www.gabisoftware.com

[16] Unpublished data provided by a standard desalination plant located in Spain (peninsula). Considering only the operation stage. Energy consumption $=1.4 \mathrm{kWh} / \mathrm{m}^{3}$ of treated water.

[17] Cashman, S., Gaglione, A., Mosley, J., Weiss, L., Hawkins, T.R., Ashbolt, N.J., Cashdollar, J., Xue, X., Ma, C. \& Arden, S., Environmental and Cost Life Cycle Assessment of Desinfection Options for Municipal Wastewater Treatment. Environmental Protection Agency (EPA): United States, 2014. 